\title{
The final straw? An overview of Straw-headed Bulbul Pycnonotus zeylanicus trade in Indonesia
}

\author{
DANIEL BERGIN, SERENE C. L. CHNG, JAMES A. EATON and \\ CHRIS R. SHEPHERD
}

\begin{abstract}
Summary
Currently listed as Endangered on the IUCN Red List of Threatened Species, the Straw-headed Bulbul Pycnonotus zeylanicus is being driven towards extinction throughout most of its range by unregulated illegal trade supplying the demand for songbirds. We conducted surveys of bird markets in North and West Kalimantan, and Central, West and East Java between July 2014 and June 2015, and observed a total of 71 Straw-headed Bulbuls in 11 markets in eight cities. Comparing our data with the literature, we found that as numbers in markets are decreasing, prices are increasing to over 20 times the prices recorded in 1987 , indicating that numbers in the wild are diminishing. This is corroborated by widespread extirpations throughout their range and reports from traders that Straw-headed Bulbuls are increasingly difficult to locate, while demand from consumers remains high. Concerted efforts from a variety of stakeholders are urgently needed to prevent the extinction of this species in the wild. We recommend that the Straw-headed Bulbul be included in Indonesia's list of protected species, considered for uplisting to Critically Endangered on the IUCN Red List and listed in Appendix I of the Convention on International Trade in Endangered Species of Wild Fauna and Flora (CITES). We also urge the Indonesian Government to effectively enforce existing laws, targeting the open bird markets to shut down the trade in this and other threatened species.
\end{abstract}

\section{Introduction}

Bird keeping has long been a popular pastime in Indonesia and retains a central place in the culture for many, especially those of Javanese descent (Nash 1993, Jepson and Ladle 2005). Birds are traded as songbirds, ornamental cage birds, novelty pets, and status symbols (Shepherd et al. 2004). While some species such as the Zebra Dove Geopelia striata and the Spotted Dove Spilopelia chinensis are captive bred on a commercial scale (Jepson and Ladle 2005), the majority of birds in trade in Indonesian markets are from the wild (Shepherd 2006, Jepson and Ladle 2011, Chng et al. 2015, Chng and Eaton 2016). The widespread and largely unregulated trade in wild birds has pushed several species to the brink of extinction, including the Javan Green Magpie Cissa thalassina, Blackwinged Myna Acridotheres melanopterus, Rufous-fronted Laughingthrush Garrulax rufifrons, Yellow-crested Cockatoo Cacatua sulphurea and Straw-headed Bulbul Pycnonotus zeylanicus (PHPA/BirdLife International-IP 1998, Muchtar and Nurwatha 2001, Shepherd et al. 2004, van Balen et al. 2011, Collar et al. 2012, Collar and van Balen 2013, Shepherd et al. 2016, Harris et al. 2016). Indonesia has a comprehensive legal system in place for safeguarding its wildlife but these laws are not adequately enforced and the illegal commercial trade of birds exists on a massive scale for the abovementioned species as well as many others (Shepherd 2006, Nijman et al. 2009, Shepherd 2010, Chng et al. 2015, Chng and Eaton 2016).

Among those species most threatened by commercial trade is the Straw-headed Bulbul, which is sold primarily for their clear, melodious song (BirdLife International 2016). This passerine 
inhabits low elevations in scrub and woodland bordering rivers, streams and other wet areas (BirdLife International 2016). Historically found throughout much of the Greater Sundas - southern Thailand, southern Myanmar, Peninsular Malaysia, Singapore, Sumatra, Borneo and Java - the species is now presumed to be extirpated from Myanmar, Thailand, Sumatra and Java because of harvest and trade (Fishpool and Tobias 2014, Eaton et al. 2015). The Straw-headed Bulbul is not listed as a protected species under Indonesian law (Government Regulation No. 7, 1999), but there is a zero quota for the harvest and trade of any wild specimens of birds where no specific quota has been set (ProFauna 2008). This means the harvest and trade of Straw-headed Bulbuls is technically illegal according to Decree of the Minister of Forestry Number 447/Kpts-II/2003. Although the species is protected in many national parks in Indonesia, where any hunting of wildlife is forbidden, it has disappeared or is in steep decline in the majority of these areas (Eaton et al. 2015).

The status of the Straw-headed Bulbul was recently reassessed on the IUCN Red List of Threatened Species and uplisted from 'Vulnerable' to 'Endangered' (BirdLife International 2016), and the wild population estimate has been updated to 1,000-2,499 individuals (BirdLife International 2016); while numbers were considered abundant in some areas as recently as 15-20 years ago, populations are in serious decline, with extirpations happening in many parts of its former range (Meijaard et al. 2005, Shepherd et al. 2013, Eaton et al. 2015, Harris et al. 2015).

In this paper we document the trade of Straw-headed Bulbuls in Indonesia using market surveys and trade data and compare these numbers to historic trade and price data, with the aim of investigating the sustainability of this trade. Research questions are: How many birds are being sold? From where are the birds sourced? Are the birds captive-bred or wild-caught? How much are they selling for? We also consult export and import data, literature, and field observations to estimate population and range decrease in the wild. Based on these, we recommend improved legal protection and enhanced enforcement for the species.

\section{Methods}

In Indonesia, we carried out market surveys in Sungai Pinyuh, Pontianak, Putussibau (West Kalimantan), Malinau (North Kalimantan), Barito, Pramuka, Jatinegara (Jakarta, West Java), Yogyakarta (Central Java), Bratang, Kupang, Turi (Surabaya in East Java) and Malang (East Java) between July 2014 and June 2015. To conduct each market survey, at least one author visited each market once and observed the displayed animals comprehensively, noting the volume of each, including the Straw-headed Bulbul. Traders openly displayed birds, allowing us to use direct observations to record the number of Straw-headed Bulbuls. We collected additional information, through informal conversations with dealers. In these conversations, vendors provided information on the sources, prices and origin (captive-bred or wild-caught) of birds. Prices recorded were the first prices given by the dealers.

In order to investigate the range reduction and population decline of this species in the wild, we compiled information from literature reviews, the Convention on International Trade in Endangered Species of Wild Fauna and Flora (CITES) trade database, and JAE's field experience, based on an average of over 50 field days a year between 2002 and 2016 in the range of the species. Data collected during market surveys were compared with the market presence reported in Nash (2003) and Shepherd et al. (2004) and prices reported in Basuni and Setiyani (1989) and Jepson and Ladle (2005). We used the currency conversion rates from July 2014 (USD $1=$ IDR $11,650)$ and June 2015 (USD $1=$ IDR 13,300).

\section{Results}

We observed Straw-headed Bulbuls in bird markets in each province surveyed during this study, with a total of 7 I individuals recorded, averaging 6.5 individuals per market (Table 1 ). We recorded the highest numbers from the markets in Central and East Java. 
Table 1. Table showing Indonesian markets surveyed, number of Straw-headed Bulbuls observed, number of shops in which the birds were observed, year in which the surveys were conducted, and first price given. Markets surveyed in which Straw-headed Bulbuls were not observed were not included here.

\begin{tabular}{|c|c|c|c|c|c|c|}
\hline Province & City - Market & Number & Shops & Year & Price range IDR & Price USD \\
\hline \multirow[t]{3}{*}{ West Kalimantan } & Sungai Pinyuh & 1 & 1 & 2015 & & \\
\hline & Pontianak & 8 & 2 & 2015 & $5,000,000-10,000,000$ & $376-751$ \\
\hline & Putussibau & $3^{\mathrm{a}}$ & 1 & 2015 & $5,000,000$ & 376 \\
\hline North Kalimantan & Malinau & $2^{\mathrm{a}}$ & 2 & 2015 & & \\
\hline \multirow[t]{3}{*}{ West Java } & Jakarta - Barito & 3 & 2 & 2014 & & \\
\hline & Jakarta - Jatinegara & 2 & 1 & 2014 & $1,000,000$ & 86 \\
\hline & Jakarta - Pramuka & 4 & 3 & 2014 & $10,000,000-12,000,000$ & $858-1030$ \\
\hline Central Java & Yogyakarta & 17 & 3 & 2015 & 8,000,000 - 16,000,000 & $602-1203$ \\
\hline \multirow[t]{3}{*}{ East Java } & Surabaya - Bratang & 12 & 5 & 2015 & $4,000,000-8,500,000$ & $301-639$ \\
\hline & Surabaya - Kupang & 4 & 2 & 2015 & $6,500,000-15,000,000$ & $489-1128$ \\
\hline & Malang & 15 & 6 & 2015 & $8,000,000$ & 602 \\
\hline
\end{tabular}

${ }^{a}$ These figures include two birds in Putussibau and two in Malinau that were observed as pets but were reported to have been bought locally.

In Kalimantan, traders reported Straw-headed Bulbuls to have been locally sourced. In Jakarta, the birds were apparently sourced from a number of localities, including Sumatra (also referred to by traders as 'Lampung' - a generic term used to describe birds from Sumatra as it's the nearest port to Java), Kalimantan, and were also frequently reported to have come from Peninsular Malaysia. In Surabaya, three birds in Kupang market were from Sumatra, and one from Kalimantan. In Malang, at least one bird was allegedly sourced from Kalimantan. Here, traders were less keen discussing birds and costs with us, possibly due to the regular presence at the market of ProFauna (a local NGO working on wildlife trade issues). In Yogyakarta, one stall had to birds that were allegedly sourced from Sumatra and Kalimantan. We believe that birds claimed to be sourced from 'Lampung' or 'Sumatra' are in actual fact originating from Malaysia, based on previous accounts from traders (Shepherd et al. 2013); furthermore numerous bird surveys on Sumatra have yielded no sightings from 2009 onwards (Eaton et al. 2015).

Traders were open about the sources of their birds. One of the birds in Bratang, a female, had a closed ring on her leg, indicating that she was captive-bred, and in Kalimantan traders revealed that five of the birds were wild-caught and the other two captive-bred. Although it is unclear what proportion of the supply of the animals are from wild sources, traders indicated that wild-caught individuals were considered superior because of their song quality. There was therefore an incentive to stock wild-caught birds over captive-bred individuals if traders could acquire them.

Prices in markets were obtained for 24 birds (see Table 1 ) and ranged from IDR 1,000,000 to IDR $16,000,000$ (USD 86 to USD 1,203), but the cheapest bird sold at Jatinegara was abnormally low. Prices were dependent on: the source of the bird; whether or not the bird had been trained; how recently the bird had been captured; the age of the bird and age at which it had been captured; the quality of the bird's song; and whether the bird was wild-caught or captive-bred. These factors, coupled with the market in which the bird was being sold, determined the price of the birds, although the exact weight of each variable could not be calculated. The median price for Strawheaded Bulbuls was IDR 7,500,000 (USD 564), $\mathrm{IDR}_{1}=5,750,000-10,000,000$ (USD 432-752). At one shop in Yogyakarta, Central Java, which held 1o birds, prices varied wildly from USD 602 to USD 1,203 purely depending on song ability. In Kalimantan, wild-caught birds commanded a higher price than captive-bred (USD 564 vs. USD 376 , respectively, in the same shop). Despite the high prices, dealers reported that buyers were common, even in remote, rural areas.

Between 1991 and 1993, 1,100 Straw-headed Bulbuls were counted in 37 out of 39 surveys carried out by TRAFFIC across Sumatra and Java (Nash 1993), an average of 30 birds per market - over four times that of our average of 6.5 birds per market. Monthly surveys over a five-year period from 
January 1997 to December 2001 across three markets in Medan (Sumatra) indicated that, although trade fluctuated (lowest number seen $=2$, highest $=86$ ) and numbers rarely exceeded 45 individuals per survey, Straw-headed Bulbuls were a constant presence in the markets, with an average of 25 birds observed per survey during 59 surveys (Shepherd et al. 2004), significantly more than were observed in markets of a similar or larger size in Java in 2014 and 2015.

Conversely, the price of Straw-headed Bulbuls is increasing. Basuni and Setiyani (1989) reported that prices in 1987 were USD 18 for an individual (the equivalent to USD 38 in 2015 based on USD inflation rates from http://www.usinflationcalculator.com/) and Jepson and Ladle (2005) reported that a typical price in 2005 was USD 120 per individual (the equivalent of USD 146 in 2015), which is very much at the lower end of the price range observed in this study.

The historic range of the Straw-headed Bulbul has decreased significantly and it is now very rare and found only in localised areas. There have been no confirmed records in Sumatra since 2009 (Eaton et al. 2015). Remaining populations in Kalimantan are confined to areas far from human habitation (Meijaard et al. 2005), and in East Malaysia (Sabah and Sarawak) it has largely disappeared from easily accessible areas in the last 15 years (J. A. Eaton pers. obs.). The current status in Brunei is unknown although five individuals were observed along the Kuala Belait River as recently as 2013 and populations may persist in areas inaccessible to poachers (Hindricks 2013). In Peninsular Malaysia it is now uncommon to scarce and has disappeared from many sites even in the last two decades (J. A. Eaton, pers. obs., eBird 2016). A recent study in Singapore estimated a minimum population of 202 individuals spread over multiple sites; this represents what is possibly the last viable population for the species in its distribution (Yong et al. 2017).

One of the authors, having spent on average over 50 field days a year between 2002 and 2016 in the range of the species, has only encountered it at four localities comprising eight pairs since 2011. This compares to nine localities found between 2002 and 2011 comprising at least 20 pairs and a small, undetermined number of single individuals in Malaysia. This includes just a single sighting, in 2007 in Indonesia (Kalimantan).

According to the CITES trade database, no Straw-headed Bulbul has been legally exported from Indonesia since it was added to Appendix II in 1997. Between 1997 and 1999, 365 Straw-headed Bulbuls were imported by Indonesia from Malaysia, with no other imports to date.

\section{Discussion}

Trade

While Straw-headed Bulbuls continue to be available in bird markets, comparing data collected during this study with the literature review shows that the number of birds has dropped dramatically while prices have increased. Exact levels of turnover are unknown, but sharp dips in numbers of birds seen in markets in Medan between 1997 and 2001 following large numbers in previous months as well as reports from traders in this study suggest a degree of turnover (Shepherd et al. 2004). Harris et al. (2015) found during 2012-2013 surveys that species experiencing population declines in the wild see rising values in the market that correspond with fewer birds. Analyses in their study put the contemporary trade volumes of Straw-headed Bulbuls at approximately $40 \%$ that of historical trade volumes, and the contemporary price at IDR $7,462,500$ is 20 times that of historical values (Harris et al. 2015).

The commercial value of the Straw-headed Bulbul is well known even in remote areas. In 2007 while undertaking a rapid bird survey in the Menyapa Mountains, a remote and difficult to access area in East Kalimantan, three freshly caught Straw-headed Bulbul chicks were found at the base camp station. These birds were intended for sale for USD 300 each to agarwood (gaharu) collectors, who would then take them to the nearest city to ultimately sell on to Jakarta (J. A. Eaton pers. obs., N. Brickle pers. comm.).

In cases where vendors provided the information, the majority of Straw-headed Bulbuls were said to have been wild-caught, although some were reportedly captive-bred. Bird keeping in 
Indonesia is more common among wealthier households (Jepson and Ladle 2005) and in some cases, rare and expensive birds (as are wild-caught individuals of this species) are attractive to buyers who consider them a status symbol (Shepherd et al. 2004, Nijman et al. 2009). Coupled with reports from dealers that frequent trade occurs, this suggests that the high price of the Straw-headed Bulbul may not be a deterrent to their purchase as pets and that this trade is therefore likely to continue even as scarcity increases.

Despite the lack of official records of trade found on the CITES trade database in recent years, traders openly admit to importing birds from neighbouring countries, indicating that illegal and unrecorded international trade in the species is taking place. The ever-present demand in Indonesia for Straw-headed Bulbuls is high, and this poses a threat to populations in neighbouring Malaysia from where birds are sourced, most likely illegally, and potentially to populations in Singapore (Nash 1993, Shepherd et al. 2013, A. Miller pers. comm.).

\section{IUCN Red List uplisting}

The status of the Straw-headed Bulbul was recently reassessed and uplisted on the IUCN Red List of Threatened Species from 'Vulnerable' to 'Endangered' (BirdLife International 2016), based on criterion $\mathrm{C}_{2} \mathrm{a}(\mathrm{i})$, whereby the species' population in the wild is $<2,500$ mature individuals, and the number of mature individuals in each subpopulation is $<250$. However, we highly recommend that further field-based research and analysis is required to establish an accurate global population estimate followed by a review for possible future uplisting to 'Critically Endangered' as local extirpations may not be sufficiently accounted for (BirdLife International 2016). Although there is a scarcity of concrete data proving this, the authors suspect that the population had already been declining at 'Critically Endangered' levels (80\% over 1o years and/or three generations) during this period.

\section{Legal protection}

Legal protection of the Straw-headed Bulbul in Indonesia is currently inadequate, as the species is not protected by law. However, capture of any wildlife in Indonesia is regulated by an annually set harvest and quota system that stipulates the numbers that can be extracted from the wild, and the location from where extraction may take place. Under the Decree of the Minister of Forestry Number 447/Kpts-II/2003 concerning the Administration Directive of Harvest and Capture and Distribution of the Specimens of Wild Plant and Animals Species, no harvest or export quota has been allocated for birds, apart from small quantities of a few select species for use as breeding stock for commercial breeding operations. There is no quota for Straw-headed Bulbuls which means no harvest from the wild is permitted. As such, anyone in possession of a wild-caught Straw-headed Bulbul is in violation of Indonesia's regulations. Dealers stated that Straw-headed Bulbuls were also smuggled into Indonesia from Malaysia, which is in violation of CITES and national laws.

\section{Recommendations}

The continual demand for the Straw-headed Bulbul, and its illegal harvest and trade to supply the demand for pets is pushing this species towards extinction. As such, we recommend the following steps be taken immediately to ensure this species is not extirpated from the wild.

1. The Indonesian authorities, namely the Natural Resources Conservation Agency (BKSDA) under the Directorate of Biodiversity Conservation (KKH), responsible for the regulation of harvest and trade in wildlife at the national level, should take immediate action to shut down the illegal trade in this and other species in the bird markets. Traders openly flouting the law should be prosecuted, with such actions being publicised so as to create a deterrent for others. 
2. The Indonesian Government is recommended to consider adding the Straw-headed Bulbul to the list of protected species as part of the ongoing review of national wildlife legislation.

3. Education and behaviour change campaigns should be designed and implemented to discourage buyers of these birds from purchasing wild-caught individuals.

4. Range countries, including Indonesia, should propose to uplist the Straw-headed Bulbul from Appendix II to Appendix I of CITES in order to accurately reflect the status of this species in the wild and the unsustainable levels of illegal international trade occurring between Malaysia and Indonesia. We consider that the Straw-headed Bulbul fulfils the biological criterion $\mathrm{C}$ for an Appendix I listing: a marked decline in wild populations inferred or projected from levels of exploitation.

5. Urgent field research in Malaysia to produce an updated global population estimate to assess for a potential uplisting on the IUCN Red List. Further surveys are encouraged in low-lying national parks in Sumatra to confirm its continued existence as the lack of sightings since 2009, despite surveys of several national parks in its historical range continuing to fail to find a single individual.

\section{Acknowledgements}

We would like to thank Richard Thomas, Thomasina Oldfield and two anonymous reviewers for reviewing an early draft of this paper, and Ban van Balen for information on Indonesian populations.

\section{References}

Basuni, S. and Setiyani, G. (1989) Studi perdagangan burung di pasar Pramuka, Jakarta dan teknik penangkapan burung di alam. Media Konservasi 2(2): 9-18.

BirdLife International (2016) Pycnonotus zeylanicus. The IUCN Red List of Threatened Species. Version 2016. http://www.iucnredlist. org/details/22712603/o Accessed o5 March 2017.

Chng, S. C. L. and Eaton, J. A. (2016) In the market for extinction: eastern and central Java. Petaling Jaya, Selangor, Malaysia: TRAFFIC.

Chng, S. C. L., Eaton, J. A., Krishnasamy, K., Shepherd, C. R. and Nijman, V. (2015) In the market for extinction: An inventory of Jakarta's bird markets. Petaling Jaya, Selangor, Malaysia: TRAFFIC.

Collar, N. J. and van Balen, S. (2013) Notes for the conservation of the Rufous-fronted Laughingthrush Garrulax rufifrons. Forktail 29: 15-18.

Collar, N.J., Gardner, L., Jeggo, D. F., Marcordes, B., Owen, A., Pagel, T., Vaidl, A., Wilkinson, R. and Wirth, R. (2012) Conservation breeding and the most threatened birds in Asia. BirdingASIA 18: 50-57.

Eaton, J. A., Shepherd, C. R., Rheindt, F. E., Harris, J. B. C., van Balen, S. (B. ), Wilcove, D. S. and Collar, N. J. (2015) Trade-driven extinctions and near-extinctions of avian taxa in Sundaic Indonesia. Forktail 31: 1-12.

eBird (2016) eBird Range Map - Strawheaded Bulbul. http://ebird.org/ebird/map/ sthbuli Accessed o5 March 2017.

Fishpool, L. and Tobias, J. (2014) Straw-headed Bulbul (Pycnonotus zeylanicus). In: J. del Hoyo, A. Elliott, J. Sargatal, D. A. Christie and E. de Juana, eds. Handbook of the birds of the world alive. Barcelona, Spain: Lynx Edicions.

Harris, J. B. C., Green, J. M., Prawiradilaga, D. M., Giam, X., Hikmatullah, D., Putra, C. A. and Wilcove, D. S. (2015) Using market data and expert opinion to identify overexploited species in the wild bird trade. Biol. Conserv. 187: 51-60.

Harris, J. B. C., Tingley, M. W., Hua, F., Yong, D. L., Adeney, J. M., Lee, T. M., Marthy, W., Prawiradilaga, D. M., Sekercioglu, C. H., Suyadi, Winarni, N. and Wilcove, D. S. (2016) Measuring the impact of the pet trade on Indonesian birds. Conserv. Biol. Accepted Author Manuscript. doi:10.1111/cobi.12729

Hindricks, F. (2013) Wetlands International surveys http://bruneiviews.blogspot.co.id/ 2013/03/wetlands-international-surveys. html Accessed o5 March 2017 
Jepson, P. and Ladle, R. J. (2005) Bird-Keeping in Indonesia: conservation impacts and the potential for substitution-based conservation responses. Oryx 39: 442-448.

Jepson, P. and Ladle, R. J. (2011) Assessing marketbased conservation governance approaches: a socio-economic profile of Indonesian markets for wild birds. Oryx 45: 482-491.

Meijaard, E., Sheil, D., Nasi, R., Augeri, D., Rosenbaum, B., Iskandar, D., Setyawati, T., Lammertink, M., Rachmatika, I., Wong, A., Soehartono, T., Stanley, S. and O'Brien, T. (2005) Life after logging: Reconciling wildlife conservation and production forestry in Indonesian Borneo. Bogor, Indonesia: CIFOR.

Muchtar, M. and Nurwatha, P. F. (2001) Gelatik Jawa dan Jalak Putih: status dan upaya konservasi di Jawa dan Bali [Java Sparrow and Black-winged Starling: status and conservation effort in Java and Bali]. Bandung, Indonesia: Yasasan Pribumi Alam Lestari.

Nash, S. (1993) Sold for a song: The trade in Southeast Asian non-CITES birds. Cambridge, UK: TRAFFIC International.

Nijman, V., Shepherd, C. R. and van Balen, S. (2009) Declaration of the Javan hawk-eagle as Indonesia's National Rare Animal impedes conservation of the species. Oryx 43:122-128.

PHPA/BirdLife International-IP (1998) Yellow-crested Cockatoo recovery plan. Bogor, Indonesia: PHPA/LIPI/BirdLife International-Indonesia Programme.

ProFauna (2008) Pirated parrots: ProFauna's investigation of the Indonesian parrot smuggling to the Philippines. Malang, Indonesia: Profauna.

Shepherd, C. R. (2006) The bird trade in Medan, North Sumatra: an overview. Birding ASIA 5: 16-24.

Shepherd, C. R. (2010) Observations on trade in laughingthrushes (Garrulax spp.) in North Sumatra, Indonesia. Bird Conserv. Internatn. 21: 86-91.

Shepherd, C. R., Sukumaran, J. and Wich, S. A. (2004) Open Season: An analysis of the pet trade in Medan, Sumatra 1997-2001. Petaling Jaya, Malaysia: TRAFFIC Southeast Asia.

Shepherd, C. R., Shepherd, L. A. and Foley, K-E. (2013) Straw-headed Bulbul Pycnonotus zeylanicus: legal protection and enforcement action in Malaysia. Birding ASIA 19: 92-94.

Shepherd, C. R., Nijman, V., Krishnasamy, K., Eaton, J. A. and Chng, S. C. L. (2016) Illegal trade pushing the Critically Endangered Black-winged Myna Acridotheres melanopterus towards imminent extinction. Bird Conserv. Internatn. 26: 147-153.

Van Balen, S., Eaton, J. A., Rheindt, F. R. (2011) Biology, taxonomy and conservation status of the Short-tailed Green Magpie Cissa [t.] thalassina from Java. Bird Conserv Internatn: 23: 91-109.

Yong, D. L., Lim, K. S., Lim, K. C., Teo, S. Y., Tan, T. and Ho, H. C. (2017) Conservation status of Singapore's population of the Straw-headed Bulbul (Pycnonotus zeylanicus): a last straw for the species? Bird Conserv. Internatn. DOI: 10.1017/So959270917000028

DANIEL BERGIN ${ }^{1,2 *}$, SERENE C. L. CHNG ${ }^{1}$, CHRIS R. SHEPHERD $^{1}$

${ }^{1}$ TRAFFIC Southeast Asia, Petaling Jaya, Malaysia.

${ }^{2}$ Oxford Wildlife Trade Research Group, Oxford Brookes, Oxford, UK.

JAMES A. EATON

Birdtour Asia, Derby, UK.

*Author for correspondence; e-mail: danielberginı@gmail.com

All authors contributed equally to this work.

Received 8 May 2016; revision accepted 13 April 2017;

Published online 16 November 2017 